\title{
Pengelolaan Sumberdaya Perikanan di Sungai Kumbe Kabupaten Merauke Provinsi Papua
}

\author{
Yoga Candra Ditya ${ }^{1}$, Mirna Dwirastina ${ }^{1}$
}

\author{
1 Balai Riset Perikanan Perairan Umum dan Penyuluhan Perikanan \\ Email : mirna.rastina@gmail.com
}

\begin{abstract}
ABSTRAK
Sungai Kumbe merupakan salah satu sungai yang berada di provinsi Papua. Karakteristik Sungai Kumbe berupa rawa banjiran dan memiliki keunikan tersendiri terutama dalam hal sumberdaya ikan. Beberapa penelitian sebelumnya telah dilakukan yang mengidikasikan bahwa Sungai kumbe telah mengalami tekanan akibat modifikasi lingkungan. Dengan demikian penelitian ini dilakukan dengan memfokuskan bagaimana pengelolaan sumber daya ikanya yang ada di Sungai Kumbe. Tujuan penelitian untuk mengetahui pengelolaan yang tepat yang harus dilakukan di Sungai Kumbe utuk menjaga kelestarian sumber daya ikan. Metode penelitian dilakukan dengan cara pendekatan metode STORET. Penelitian dilakukan di Sungai Kumber tahun 2014 dan 2015. Hasil penelitian menunjukkan bahwa untuk keberlajutan sumberdaya ikan diperlukan langkah-langkah pengelolaan meliputi (1) rehabilitasi hutan rawa, (2) penetapan suaka perikanan/konservasi, (3) pengelolaan perikanan, (4) pengembangan co-management.
\end{abstract}

Kata kunci: Pengelolaan, Sumber Daya Ikan, Sungai Kumbe, Papua

\begin{abstract}
Kumbe River is one of the rivers in the province of Papua. The characteristics of the Kumbe River are in the form of swamp floods and have their own uniqueness, especially in terms of fish resources. Several previous studies have been conducted which indicate that the Kumbe River has been under pressure due to environmental modification. Thus this research was conducted by focusing on how to manage fish resources in the Kumbe River. The research objective is to determine the proper management that must be carried out in the Kumbe River to preserve fish resources. The research method was carried out by means of the STORET method approach. The study was conducted in the Kumber River in 2014 and 2015. The results showed that for sustainability of fish resources management steps needed include (1) rehabilitation of swamp forests, (2) determination of fishery reserves / conservation, (3) fisheries management, (4) development co-management.
\end{abstract}

Keywords: Management, Fish Resources, Kumbe River, Papua

Citation: Ditya, Y. C., Dwirastina, M. (2019). Pengelolaan Sumberdaya Perikanan di Sungai Kumbe Kabupaten Merauke Provinsi Papua. Jurnal Ilmu Lingkungan, 17(3),435-442, doi:10.14710/jil.17.3.435-442

\section{PENDAHULUAN}

Sungai Kumbe merupakan bagian dari wilayah sungai Einlanden-Digul-Bikuma, dengan bercirikan sungainya relatif lebar, cenderung berkelok-kelok (meander) dan memiliki wilayah rawa banjiran yang luas pada musim penghujan (JCP, 2012; Djohan, 2008; PP 26 tahun 2008).

Berdasarkan penelitian yang dilakukan Ditya et al., (2014) menemukan beberapa jenis ikan yaitu nila (Oreochromis niloticus), gabus/gastor (Channa striata), lele (Clarias batrachus), betik (Anabas testudineus), kakap rawa (Hephaestus raymondi), kakap batu (Pingalla lorentzi), sembilang (Neosilurus ater), duri (Neoarius graeffei), udang (Macrobrachium rosenbergii), sumpit (Toxotes jaculatrix), tulang (Nematalosa flyensis), julungjulung (Strongylura kreffti) dan mata bulan
(Megalops cyprinoides). Dari beberapa jenis ikan hasil tangkapan tersebut yang berpotensi sebagai ikan konsumsi seperti ikan kakap rawa (Hephaestus raymondi), udang (Macrobrachium rosenbergii), duri (Neoarius graeffei), tulang (Nematalosa flyensis), julung-julung (Strongylura kreffti)dan sembilang (Neosilurus ater),sedangkan yang berpotensi sebagai ikan hias antara lain arwana (Scleropages jardinii), sumpit (Toxotes jaculatrix), kakap batu (Pingalla lorentzi) dan pelangi (Melanotaenia goldie).

Keanekaragaman jenis ikan yang ditemukan di Sungai Kumbe dan potensi yang dapat dimanfaatkan memberikan perhatian bahwa pengelolaan perikanan diperlukan untuk keberlanjutan sumberdaya ikan. Pengelolaan tersebut bertujuan untuk memastikan bahwa kapasitas ekosistem akuatik dalam menghasilkan 
ikan, keuntungan dan manfaat, kelangsungan tenaga kerja, dan yang lebih umum lagi jasa penting dan kehidupan masyarakat secara tak terbatas dipelihara untuk manfaat bagi generasi sekarang dan yang akan datang (Kartamihardja et al., 2013). Oleh karena itu, informasi mengenai karakteristik habitat dan sumberdaya perikanan, status pemanfaatan serta upaya pengelolaan perikanan menjadi penting, dan diharapkan dapat menjadi bahan pertimbangan bagi pemangku kepentingan dalam mengambil kebijakan mengenai pengelolaan perikanan khususnya di Sungai Kumbe.

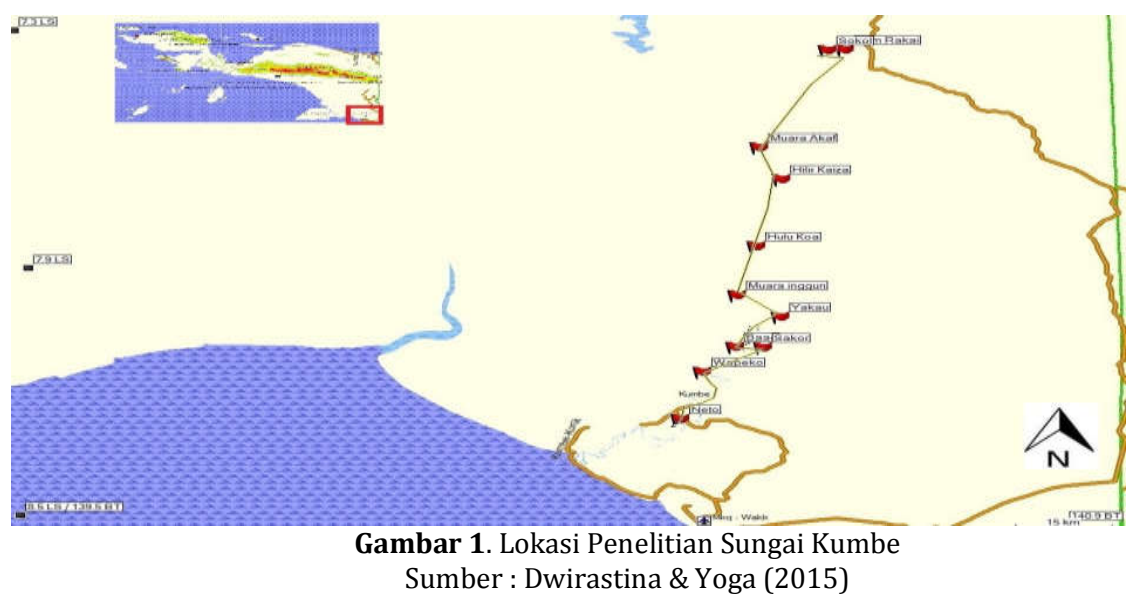

\section{BAHAN DAN METODE}

Penelitian dilakukan di Sungai Kumbe, Kabupaten Merauke Papua (Gambar 1) pada bulan Maret, Mei dan September 2014 dan 2015. Lokasi stasiun pengambilan sampel yaitu:Alfasera, Wapeko,Yakau, Baad, Inggun, dan Sakor. Metode pendekatan lingkungan digunakan adalah metode STORET. Metode STORET ini adalah suatu metode dengan membandingkan hasil analisa kimia air dengn baku mutu air sesuai pemanfaatan air yaitu untuk sumber air bagi biota perairan. Kualitas air dinilai berdasarkan ketentuan sistem STORET yang dikeluarkan oleh EPA (Environmental Protection Agency, Canter, 1977).

Analisa Data dilakukan secara deskriftip dari variable penelitian yang diambil.

\section{HASIL DAN PEMBAHASAN}

\section{Karakteristik Habitat Sungai Kumbe}

Modifikasi lingkungan yang terjadi di sepanjang Sungai Kumbe terutama di bagian hulu sungai i adalah banyak kawasan hutan yang telah dikonversi untuk perkebunan dan keperluan. Namun demikian, kondisi hutan cenderung masih alami di rawa Sungai Kumbe bagian tengah sehingga merupakan habitat yang baik bagi pertumbuhan ikan dan larva ikan (Gambar 2).

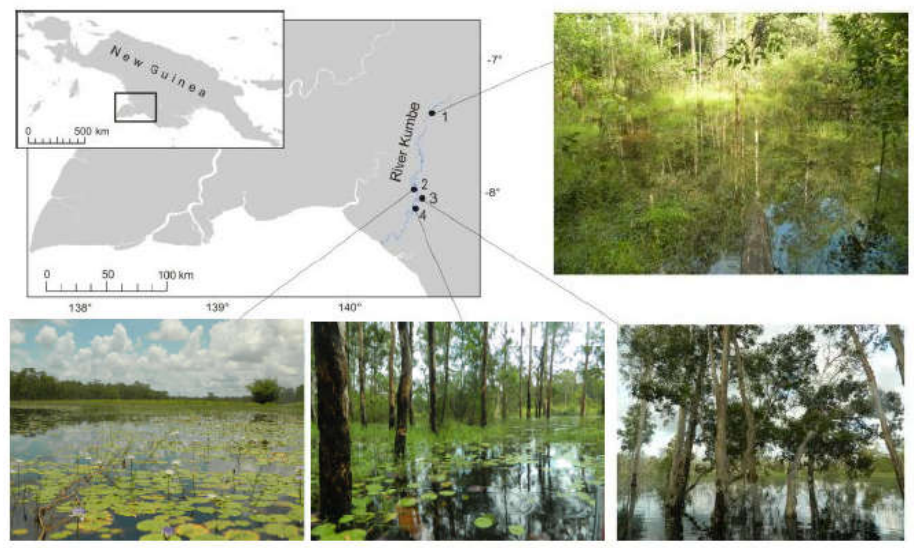

Gambar 2 Tipe rawa di Sungai Kumbe, Alfasera (1), Inggun (2), Yakau (3) dan Sakor (4)

Kualitas fisika dan kimia perairan di sepanjang Sungai Kumbe menunjukkan bahwa hampir semua parameter fisika dan kimia perairan masih dalam batas yang ditetapkan dalam baku mutu kualitas air kelas III (Tabel 1). Baku mutu kualitas air kelas III diperuntukan untuk pembudidayaan ikan air tawar, peternakan, mengairi pertanaman, dan peruntukan lain yang mempersyaratkan mutu air yang sama dengan kegunaan tersebut (PP No. 82 Tahun 2001). Hasil analisa dengan menggunakan pendekatan metode storage and retrieval of water quality data system (STORET) yang mengacu pada Kepmen LH No. 115 Tahun 2003 didapatkan tingkat tekanan lingkungan perairan di Sungai Kumbe. Pada bagian 
hulu dan tengah tergolong tercemar sedang untuk peruntukan baku mutu air kelas III dengan skor kurang dari lima untuk parameter fisika dan skor kurang dari 10 untuk parameter kimia (Tabel 2). Kandungan total suspended solid (TSS) lebih dari 400 $\mathrm{mg} / \mathrm{L}$ serta kandungan $\mathrm{NH}_{3}$ lebih dari 0,02 mg/L memberikan kontribusi besar terhadap penurunan kualitas air di Sungai Kumbe (Tabel 1). Tingginya kandungan kedua parameter kemungkinan berkaitan dengan limpasan air dari lahan teresterial di sepanjang Sungai Kumbe (Ditya et al., 2014).

Tingkat tekanan lingkungan perairan di Sungai Kumbe secara spasial menunjukkan tingkat pencemaran yang cenderung sama pada kategori sedang namun pada stasiun Wapeko terlihat jelas kandungan TSS yang lebih besar dari $400 \mathrm{mg} / \mathrm{L}$ dan $\mathrm{NH}_{3}$ yang lebih besar dari 0,02 mg/L. Berdasarkan hasil uji STORET di Sungai Kumbe, tekanan lingkungan diakibatkan oleh pasokan TSS dan $\mathrm{NH}_{3}$. Kandungan TSS dengan nilai $>400 \mathrm{mg} / \mathrm{L}$ dikategorikan memiliki pengaruh yang tidak baik untuk kepentingan perikanan (Alabaster \& Lloyd, 1982 dalam Effendie, 2003). TSS yang sangat tinggi ini akan meningkatkan nilai kekeruhan dan akan menghambat penetrasi cahaya matahari ke kolom air sehingga akan berpengaruh terhadap proses fotosintesis di perairan. Sedangkan $\mathrm{NH}_{3}$ di perairan bersumber dari pemecahan nitrogen organik (protein dan urea) dan nitrogen anorganik yang terdapat di dalam tanah dan air, yang berasal dari dekomposisi bahan organik oleh mikroba dan jamur (Effendie, 2003).Nilai amoniak di perairan tergolong tinggi untuk perikanan dimana nilainya melebihi 0,02 mg/l.Nilai ammonia bebas diatas $0,2 \mathrm{mg} / \mathrm{L}$ bersifat toksik bagi beberapa jenis ikan (Sawyer \& McCarty,1978 dalam Effendie, 2003).

Penelitian Husnah \& Wibowo (2012) menyatakan tingginya kandungan TSS umumnya terjadi pada saat setelah hujan dan akan mengindikasikan deposisi partikel tersuspensi yang berasal dari lahan terbuka di bagian hulu dan tengah Sungai. Sedangkan kandungan $\mathrm{NH}_{3}$ yang melewati ambang batas baku mutu kelas III diperkirakan berkaitan dengan limpasan pupuk pertanian dan limbah domestik yang dibawa arus dan masuk kedalam sungai (Prianto et al., 2010).

Tabel 1. Hasil Analisis Parameter Fisika Kimia Perairan di Sungai Kumbe, Papua

\begin{tabular}{|c|c|c|c|c|c|c|c|c|c|c|c|c|c|c|c|c|c|}
\hline \multirow[b]{2}{*}{ No } & \multirow[b]{2}{*}{ Parameter } & \multirow{2}{*}{$\begin{array}{c}\text { Baku } \\
\text { Mutu III }\end{array}$} & \multicolumn{3}{|c|}{ Baad } & \multicolumn{3}{|c|}{ Sakor } & \multicolumn{3}{|c|}{ Yakau } & \multicolumn{3}{|c|}{ Wapeko } & \multicolumn{3}{|c|}{ Inggun } \\
\hline & & & Min & Maks & $\begin{array}{c}\text { Rata- } \\
\text { rata }\end{array}$ & Min & Maks & $\begin{array}{l}\text { Rata- } \\
\text { rata }\end{array}$ & Min & Maks & $\begin{array}{l}\text { Rata- } \\
\text { rata }\end{array}$ & Min & Maks & $\begin{array}{l}\text { Rata- } \\
\text { rata }\end{array}$ & Min & Maks & $\begin{array}{l}\text { Rata- } \\
\text { rata }\end{array}$ \\
\hline 1 & $\begin{array}{l}\text { Suhu Air } \\
\left({ }^{\circ} \mathrm{C}\right)\end{array}$ & Deviasi 3 & 29.7 & 32 & 30.85 & 29.3 & 30.8 & 30.05 & 29.9 & 31.5 & 30.7 & 28.8 & 31.7 & 30.25 & 29.2 & 30 & 29.6 \\
\hline 2 & $\begin{array}{l}\text { TDS } \\
(\mathrm{mg} / \mathrm{L})\end{array}$ & 1000 & 5.5 & 6.2 & 5.85 & 4.8 & 5.9 & 5.35 & 5 & 6 & 5.5 & 5.2 & 7.6 & 6.4 & 5.4 & 6.1 & 5.75 \\
\hline 3 & $\begin{array}{l}\text { TSS } \\
(\mathrm{mg} / \mathrm{L})\end{array}$ & 400 & 0.02 & 0.0738 & 0.0469 & 0.02 & 0.0328 & 0.0264 & 0.0174 & 0.002 & 0.0097 & 0.0267 & 0.007 & 0.01685 & 0.02 & 0.0246 & 0.0223 \\
\hline 4 & $\mathrm{pH}$ & $6,0-9,0$ & 0.109 & 0.448 & 0.2785 & 0.0099 & 0.647 & 0.32845 & 0.119 & 0.163 & 0.141 & 0.16 & 0.592 & 0.376 & 0.052 & 0.1 & 0.076 \\
\hline 5 & $\begin{array}{l}\text { COD } \\
(\mathrm{mg} / \mathrm{L})\end{array}$ & 50 & 1.08 & 7.32 & 4.2 & 1.66 & 3.83 & 2.745 & 1.16 & 5.99 & 3.575 & 1 & 4.16 & 2.58 & 1.41 & 3.83 & 2.62 \\
\hline \multirow[t]{2}{*}{6} & $\begin{array}{l}\text { DO } \\
(\mathrm{mg} / \mathrm{L})\end{array}$ & 3 & 1.15 & 4.28 & 2.715 & 1.65 & 3.91 & 2.78 & 1.08 & 5.31 & 3.195 & 1.2 & 6.5 & 3.85 & 1.68 & 3.35 & 2.515 \\
\hline & $\begin{array}{l}\mathrm{TP} \\
(\mathrm{mg} / \mathrm{L})\end{array}$ & 1 & 0.02 & 0.0738 & 0.0469 & 0.02 & 0.0328 & 0.0264 & 0.0174 & 0.02 & 0.0187 & 0.0267 & 0.07 & 0.04835 & 0.02 & 0.0246 & 0.0223 \\
\hline 7 & $\begin{array}{l}\mathrm{NO}_{3} \\
(\mathrm{mg} / \mathrm{L})\end{array}$ & 20 & 0.109 & 0.448 & 0.2785 & 0.099 & 0.647 & 0.373 & 0.119 & 0.163 & 0.141 & 0.16 & 0.592 & 0.376 & 0.0052 & 0.1 & 0.0526 \\
\hline 8 & $\begin{array}{l}\mathrm{NH}_{3} \\
(\mathrm{mg} / \mathrm{L})\end{array}$ & $\leq 0,02$ & 0.048 & 0.138 & 0.093 & 0.0028 & 0.0064 & 0.0046 & 0.047 & 0.163 & 0.105 & 0.161 & 0.182 & 0.1715 & 0.019 & 0.105 & 0.062 \\
\hline 9 & $\begin{array}{l}\mathrm{NO}_{2} \\
(\mathrm{mg} / \mathrm{L})\end{array}$ & 0,06 & 0.0014 & 0.00027 & 0.000835 & 0.0023 & 0.0027 & 0.0025 & 0.0014 & 0.0029 & 0.00215 & 0.0055 & 0.0184 & 0.01195 & 0.0019 & 0.0033 & 0.0026 \\
\hline
\end{tabular}

Tabel 2. Hasil pengukuran in deks storet beberapa parameter fisika kimia perairan Sungai Kumbe

\begin{tabular}{|c|c|c|c|c|c|c|c|}
\hline \multirow{2}{*}{ No } & \multirow{2}{*}{ Parameter } & \multirow{2}{*}{ Baku Mutu III } & \multicolumn{5}{|c|}{ Indeks Storet } \\
\hline & & & Baad & Sakor & Yakau & Wapeko & Inggun \\
\hline 1 & Suhu Air $\left({ }^{\circ} \mathrm{C}\right)$ & Deviasi 3 & -3 & -5 & -5 & -3 & -5 \\
\hline 2 & TDS (mg/L) & 1000 & 0 & 0 & 0 & 0 & 0 \\
\hline 3 & TSS (mg/L) & 400 & 0 & 0 & 0 & -4 & 0 \\
\hline 4 & $\mathrm{pH}$ & $6-9$ & 0 & 0 & 0 & 0 & 0 \\
\hline 5 & $\mathrm{COD}(\mathrm{mg} / \mathrm{L})$ & 50 & 0 & 0 & 0 & 0 & 0 \\
\hline 6 & $\mathrm{DO}(\mathrm{mg} / \mathrm{L})$ & 3 & -8 & -8 & -2 & -2 & -8 \\
\hline 7 & $\mathrm{TP}(\mathrm{mg} / \mathrm{L})$ & 1 & 0 & 0 & 0 & 0 & 0 \\
\hline 8 & $\mathrm{NO}_{3}(\mathrm{mg} / \mathrm{L})$ & 20 & 0 & 0 & 0 & 0 & 0 \\
\hline 9 & $\mathrm{NH}_{3}(\mathrm{mg} / \mathrm{L})$ & $\leq 0,02$ & -2 & -4 & -10 & -10 & -8 \\
\hline \multirow[t]{3}{*}{10} & $\mathrm{NO}_{2}(\mathrm{mg} / \mathrm{L})$ & 0,06 & 0 & 0 & 0 & 0 & 0 \\
\hline & Jumlah & & -13 & -17 & -17 & -19 & -26 \\
\hline & Hasil Penilaian & & Sedang & Sedang & Sedang & Sedang & Sedang \\
\hline
\end{tabular}




\section{Karakteristik Sumberdaya Perikanan}

Kegiatan penangkapan ikan di Sungai Kumbe pada umumnya dilakukan nelayan setempat bersamaan dengan melakukan kegiatan berburu di hutan.Jenis alat tangkap yang digunakan untuk menangkap ikan bervariasi seperti jala, jaring, dan pancing, dengan alat tangkap utama jaring.Hasil tangkapan per upaya penangkapan bervariasi tergantung jenis alat tangkap, waktu dan lokasi penangkapan. Alat tangkap jala, jaring dan pancing dioperasikan sepanjang tahun dengan hasil tangkapan bervariasi antara 1,0-13,3 kg/hari. Hasil tangkapan yang tinggi dengan kisaran 6,6-13,3 $\mathrm{kg} /$ hari didapatkan dari alat tangkap jaring dengan hasil tangkapan utamanya ikan duri (Neoarius graeffei).

Pada bagian hulu dan tengah Sungai Kumbe, hasil tangkapan ikan didominasi oleh jenis ikan asli Papua yang merupakan bagian dari distribusi ikanikan Paparan Sahul (Rahardjo et al., 2011) seperti ikan duri (Neoarius graeffei), ikan mata bulan (Megalops cyprinoides) dan ikan tulang (Nematalosa flyensis). Ikan-ikan tersebut merupakan jenis ikan yang sering ditemukan di sepanjang Sungai Kumbe.
Hal ini menunjukkan bahwa ikan-ikan tersebut memiliki dinamika spasial dalam hal distribusi ruaya paling luas dibandingkan dengan jenis ikan lainnya.Ruaya merupakan aktivitas penting bagi ikan yang merupakan bagian dari daur hidupnya. Menurut Utomo et al (2010), tujuan ruaya ikan di perairan umum dapat dibedakan menjadi tiga jenis yaitu ruaya pemijahan, ruaya untuk mencari makan, dan ruaya untuk menghindar dari lingkungan yang kurang baik.

Jika diperhatikan berdasarkan dinamika temporal waktu pengamatan Maret dan September terlihat bahwa jenis ikan duri (Neoarius graeffei) merupakan jenis ikan yang sering ditemukan di sepanjang waktu pengamatan diikuti dengan ikan mata bulan (Megalops cyprinoides), ikan tulang (Nematalosa flyensis) dan ikan saku (Strongylura kreffti).Hal ini memungkinkan bahwa jenis ikan-ikan tersebut secara temporal merupakan jenis ikan yang dominan tertangkap dan memiliki ruaya pada lokasi yang sama dan ini mengindikasikan ekosistem yang masih mendukung untuk kehidupan ikan-ikan tersebut (Ditya et al., 2014).

Tabel 3. Beberapa jenis ikan introduksi yang ditemukan di Sungai Kumbe

\begin{tabular}{|c|c|c|c|c|c|}
\hline \multirow[b]{2}{*}{ Lokasi } & \multicolumn{5}{|c|}{ Nama jenis ikan } \\
\hline & $\begin{array}{c}\text { Betik (Anabas } \\
\text { testudineus) }\end{array}$ & $\begin{array}{l}\text { Gastor(Channa } \\
\text { striata) }\end{array}$ & $\begin{array}{c}\text { Nila (Oreochromis } \\
\text { niloticus) }\end{array}$ & $\begin{array}{c}\text { Mujair } \\
\text { (Oreochromis } \\
\text { mossambicus) }\end{array}$ & $\begin{array}{l}\text { Lele (Clarias } \\
\text { batrachus) }\end{array}$ \\
\hline Alfasera & $\sqrt{ }$ & $\sqrt{ }$ & $\sqrt{ }$ & $\sqrt{ }$ & \\
\hline Wayau & $\sqrt{ }$ & $\sqrt{ }$ & $\sqrt{ }$ & $\sqrt{ }$ & $\sqrt{ }$ \\
\hline Baad & $\sqrt{ }$ & $\sqrt{ }$ & $\sqrt{ }$ & $\sqrt{ }$ & $\sqrt{ }$ \\
\hline Wapeko & $\sqrt{ }$ & $\sqrt{ }$ & $\sqrt{ }$ & & $\sqrt{ }$ \\
\hline
\end{tabular}

Penelitian Ditya et al., (2014) diperoleh beberapa jenis ikan introduksi yang ditemukan di Sungai Kumbe(Tabel 3).Namun demikian keberadaan ikan introduksi seperti nila (Oreochromis niloticus), gastor (Channa striata) dan betik (Anabas testudineus) kurang dominan jika dibandingkan keberadaan ikan asli Papua.Hal ini dikarenakan masyarakat setempat juga memanfaatkan ikan-ikan introduksi tersebut sebagai target tangkapan terutama untuk konsumsi sehingga aktivitas tersebut secara tidak langsung juga turut mengontrol perkembangan populasinya di alam agar tidak bersifat invasive (Sentosa \& Satria, 2013).

\section{Status Pemanfaatan Sumberdaya Perikanan}

Pemanfaatan sumberdaya perikanan di Sungai Kumbe telah berlangsung sejak lama.Informasi yang diperoleh dari wawancara nelayan menunjukkan bahwa nelayan setempat telah melakukan kegiatan perikanan tangkap sejak 10-20 tahun yang lalu.Ratarata pengalaman responden nelayan di kegiatan perikanan tangkap adalah 17 tahun dengan rata-rata alokasi waktu kerja 5 jam/hari dimulai dari pukul 10.00 WIT hingga 15.00 WIT.

Tingkat pemanfaatan sumberdaya perikanan di Sungai Kumbe berdasarkan lokasi pengamatan bervariasi.Hal ini tentu sangat dipengaruhi oleh jenis alat tangkap yang digunakan, ketersediaan sumberdaya perikanan dan karakteristik habitat pendukung sumberdaya tersebut. Jenis alat tangkap yang digunakan antara lain jaring, jala dan pancing. Hampir keseluruhan jenis alat tangkap tersebut digunakan oleh nelayan di Sungai Kumbe.

Tabel 4. Total hasil tangkapan ikan per tahun menurut lokasi pada tahun 2005, 2010 dan 2014 serta upaya penangkapan dan CPUE tahun 2014.

\begin{tabular}{|c|c|c|c|c|c|}
\hline \multirow[t]{2}{*}{ Lokasi } & \multicolumn{3}{|c|}{$\begin{array}{c}\text { Hasil tangkapan } \\
\text { (ton/tahun) }\end{array}$} & \multirow{2}{*}{$\begin{array}{c}\begin{array}{c}\text { Upaya } \\
(\Sigma \text { Nelayan })\end{array} \\
2014\end{array}$} & \multirow{2}{*}{$\begin{array}{c}\text { CPUE (ton) } \\
2014\end{array}$} \\
\hline & 2005 & 2010 & 2014 & & \\
\hline Alfasera & 0,78 & 0,36 & 0,36 & 12 & 0,03 \\
\hline Wayau & 3,60 & 4,80 & 4,80 & 37 & 0,13 \\
\hline Baad & 4,80 & 4,80 & 3,60 & 20 & 0,18 \\
\hline Wapeko & 3,60 & 3,60 & 3,60 & 11 & 0,33 \\
\hline
\end{tabular}

Sumber: FGD Tahun 2014 
Informasi yang diperoleh dari nelayan dan terlihat bahwa selama selama sembilan tahun terakhir total hasil tangkapan ikan bervariasi (Tabel 4). Di daerah Alfasera yang merupakan daerah hulu Sungai Kumbe pada tahun 2014 diperoleh total hasil tangkapan ikan 0,36 ton/tahun. Di daerah Wayau yang merupakan ibukota distrik total hasil tangkapan ikan 4,80 ton/tahun, sedangkan di wilayah Baad dan
Wapeko total hasil tangkapan ikan 3,60 ton/tahun.Upaya pemanfaatan sumberdaya perikanan di Sungai Kumbe berdasarkan pada jumlah nelayan dapat dilihat pada Tabel 2 dengan memperhatikan lokasi terdiri dari 11 hingga 37 nelayan yang aktif melakukan kegiatan perikanan tangkap di masing-masing lokasi.

Tabel 5 Hasil tangkapan per jenis ikan menurut bobot $(\mathrm{kg})$ pada musim air tinggi dan air surut menurut wilayah.

\begin{tabular}{|c|c|c|c|c|c|c|c|c|}
\hline \multirow{3}{*}{ Jenis Ikan } & \multicolumn{8}{|c|}{ Berat ikan hasil tangkapan (kg) menurut wilayah } \\
\hline & \multicolumn{4}{|c|}{ Air Tinggi } & \multicolumn{4}{|c|}{ Air Rendah } \\
\hline & Alfasera & Wayau & Baad & Wapeko & Alfasera & Wayau & Baad & Wapeko \\
\hline $\begin{array}{l}\text { Arwana (Scleropages } \\
\text { jardinii) }\end{array}$ & - & $<2$ & - & - & - & $<2$ & - & - \\
\hline $\begin{array}{l}\text { Betik (Anabas } \\
\text { testudineus) }\end{array}$ & - & $>10$ & - & - & $<2$ & $>10$ & $>10$ & $>10$ \\
\hline Duri (Neoarius graeffei) & $2-5$ & $>10$ & $5-10$ & $5-10$ & - & $>10$ & $2-5$ & $5-10$ \\
\hline Gastor (Channa striata) & $5-10$ & - & - & - & $>10$ & $>10$ & $>10$ & $>10$ \\
\hline $\begin{array}{l}\text { Kakap Rawa } \\
\text { (Hephaestus raymondi) }\end{array}$ & - & $>10$ & $5-10$ & $>10$ & $<2$ & $>10$ & $>10$ & - \\
\hline $\begin{array}{l}\text { Mata Bulan (Megalops } \\
\text { cyprinoides) }\end{array}$ & $2-5$ & $2-5$ & $2-5$ & $5-10$ & $2-5$ & $5-10$ & $5-10$ & - \\
\hline $\begin{array}{l}\text { Nila (Oreochromis } \\
\text { niloticus) }\end{array}$ & - & $>10$ & $5-10$ & - & $2-5$ & $>10$ & $5-10$ & $>10$ \\
\hline $\begin{array}{l}\text { Sembilang (Neosilurus } \\
\text { ater) }\end{array}$ & $2-5$ & $>10$ & $5-10$ & - & $2-5$ & - & - & - \\
\hline $\begin{array}{l}\text { Sumpit (Toxotes } \\
\text { jaculatrix) }\end{array}$ & $<2$ & $<2$ & - & $5-10$ & $<2$ & $5-10$ & $5-10$ & - \\
\hline $\begin{array}{l}\text { Tulang (Nematalosa } \\
\text { flyensis) }\end{array}$ & $2-5$ & $>10$ & - & - & $2-5$ & $>10$ & $>10$ & $2-5$ \\
\hline $\begin{array}{l}\text { Udang(Macrobrachium } \\
\text { rosenbergii) }\end{array}$ & - & - & - & - & $<2$ & $>10$ & $>10$ & - \\
\hline
\end{tabular}

Hasil tangkapan per jenis ikan menurut bobot pada musim air tinggi dan air surut (Tabel 5).Ada beberapa jenis ikan yang dominan tertangkap pada musim air rendah dan sebaliknya pada musim air tinggi seperti ikan betik dan gastor.Dari ukuran jenis ikan yang tertangkap didominasi oleh ukuran ikan yang $>10 \mathrm{~kg}$.Hal ini mengindikasikan kondisi alam yang masih alami untuk mendukung pertumbuhan jenis-jenis ikan yang ada di Sungai Kumbe (Ditya et al, 2014)

\section{Permasalahan Pengelolaan Perikanan}

Modifikasi lingkungan atau perubahan antrophogenik terutama pada bagian hulu seperti kawasan hutan yang dikonversi menjadi perkebunan dan keperluan lain tentunya berpengaruh terhadap migrasi dan ruaya ikan bahkan berpengaruh juga terhadap keberadaan stok sumberdaya ikan akibat terganggunya keseimbangan habitat untuk pertumbuhan ikan dan larva ikan. Hal ini telah terlihat dari tekanan lingkungan perairan Sungai Kumbe yang berada pada kategori sedang akibat pasokan TSS dan $\mathrm{NH}_{3}$ yang umumnya dicirikan dengan limpasan air dari lahan teresterial di bagian sungai yang mengalami modifikasi.

Jika habitat alami dan kondisi lingkungan mengalami tekanan maka dikhawatirkan keberadaan beberapa jenis ikan asli Papua seperti ikan duri (Neoarius graeffei), ikan mata bulan (Megalops cyprinoides), ikan tulang (Nematalosa flyensis) dan ikan saku (Strongylura kreffti)memungkinkan akan terganggu dan tergantikan dengan keberadaan ikan- ikan introduksi..Oleh karena itu, keberadaan suaka perikanan atau reservat sangat penting untuk keberlangsungan stok sumberdaya ikan karena merupakan tempat perlindungan ikan dan berkembang biak dengan baik (Utomo, 2016; Umar et al., 2015). Namun sampai saat ini belum ada reservat atau suaka perikanan di Sungai Kumbe dan aktivitas penangkapan masih dilakukan secara bebas.

Aktivitas penangkapan yang dilakukan secara bebas oleh masyarakat setempat telah berlangsung puluhan tahun lamanya dengan menggunakan alat tangkap seperti jaring, jala dan pancing.Namun kelompok nelayan belum terbentuk secara formal padahal untuk keperluan pengelolaan sumberdaya ikan diperlukan unit kelembagaan yang unsurnya keterlibatan masyarakat setempat.

\section{Pengelolaan Perikanan}

Pengelolaan yang dapat dilakukan sebagai upaya dalam menjaga kelestarian dan keberlanjutan sumberdaya perikanan di Sungai Kumbe antara lain:

\section{Pengelolaan penangkapan}

Pengaturan waktu dan lokasi penangkapan perlu diperhatikan dengan baik, terutama saat ikan akan melakukan pemijahan. Ikan-ikan rawa banjiran umumnya akan melakukan pemijahan ketika air mulai naik hingga banjir maksimal maka sebaiknya aktivitas penangkapan tidak dilakukan di perairan yang menghubungkan sungai dan rawa. Aktivitas penangkapan masih dapat dilakukan di sungai dengan menggunakan alat tangkap yang selektif seperti pancing. 
2. Rehabilitasi hutan rawa dan pemeliharaan vegetasi riparian

Sungai Kumbe merupakan sungai di Paparan Sahul memiliki empat tipe habitat yaitu habitat rawa banjiran di tepi sungai, habitat tipe rerumputan, habitat tipe tumbuhan semak belukar dan habitat tipe cabang-cabang pohon (Kartamihardja et al, 2013). Keempat habitat tersebut merupakan ciri dari hutan rawa yang keberadaannya semakin mengalami penurunan luasan.Oleh karena itu, rehabilitasi hutan rawa dan pemeliharaan vegetasi riparian diperlukan untuk mendukung keberadaan habitat pemijahan ikan-ikan rawa banjiran seperti ikan duri (Neoarius graeffei), ikan mata bulan (Megalops cyprinoides) dan ikan tulang (Nematalosa flyensis).

3. Penetapan suaka perikanan /reservat

Pengembangan suaka perikanan perlu dilakukan sebagai wilayah pemijahan, asuhan dan pembesaran.Hal ini tentu dengan mempertimbangkan karakteristik kesesuaian habitat agar ikan-ikan dapat dilindungi dan pelibatan masyarakat nelayan setempat diperlukan agar pengelolaannya efektif.Salah satu lokasi yang direkomendasikan adalah Rawa Sakor dan Rawa Inggun sebagai habitat juvenile dan ikan asli papua.

4. Pengembangan co-management

Salah satu bentuk pengelolaan perikanan yang berkelanjutan dengan pelibatan masyarakat secara aktif adalah sistem co-management. Pengelolaan sumberdaya ikan yang juga dengan memperhatikan tingkat pemanfaatan sumberdaya ikan di Sungai Kumbe yang sangat ditentukan pada karakteristik penduduk yang ada di wilayah tersebut misalnya pada Wapeko hingga Kaiza didominasi oleh suku "marind" yang merupakan suku asli Papua dan 50\% kehidupan masyarakatnya bergantung pada perikanan dengan tingkat pemanfaatan sumberdaya perikanan berada pada kisaran 1-13,3 kg/hari. Sedangkan untuk daerah Seed Agung dan Salor ke arah muara Kumbe sudah didominasi oleh masyarakat pendatang kegiatan perikanan sudah tidak dominan. Selain itu, kepemilikan lahan yang dimiliki oleh warga setempat berkisar pada 0,5-2,0 ha yang digunakan untuk kegiatan sawah dan ladang. Sebagian besar masyarakat beranggapan bahwa sumberdaya ikan yang ada di Sungai Kumbe merupakan milik masyarakat (communal property). Hak kepemilikan sumberdaya ini akan berimplikasi pada hak pemanfaatan (access rights). Menurut Kartamihardja et al (2013), dengan co-management dimungkinkan secara adaptif untuk dapat menyeimbangkan kepentingan masyarakat dan swasta sebagai pengguna dengan pemerintah dan lembaga otoritas suatu perairan umum sebagai pengelola.

\section{KESIMPULAN}

Pengelolaan yang harus dilakukan untuk menjamin sumberdaya perikanan diperlukan langkah-langkah pengelolaan sebagai berikut: (1) rehabilitasi hutan rawa, (2) penetapan suaka perikanan / reservat, (3) pengelolaan penangkapan, (4) pengembangan co-management dengan prinsip keterpaduan dan koordinasi yang mengutamakan kearifan lokal sehingga tercipta sinergi dalam pemanfaatan sumberdaya dengan saling menghormati dan bertanggung jawab.

\section{DAFTAR PUSTAKA}

Bengen, D.G. (2004). Sinopsis ekosistem dan sumberdaya alam pesisir dan laut serta prinsip pengelolaannya.Pusat kajian sumberdaya pesisir dan lautan Institut Pertanian Bogor.

BPDAS Mamberamo.(2013). Peta pemanfaatan lahan dan kawasan hutan di sepanjang Sungai Kumbe, Papua.

Ditya, Y.C., Husnah, Gaffar, A.K., Muflikhah, N., Wibowo, A., Kaban, S., Marini, M., Wulandari, T.N.M., Dwirastina, M., Burnawi, Apriyadi, Junianto, R. S., Mersi, Rusmaniar, \& Nasution, D. (2014).Potensi dan Pemanfaatan Sumberdaya Perikanan di Perairan Sungai Kumbe Kabupaten Merauke Provinsi Papua(p. 79).Laporan Akhir Tahun Kegiatan Penelitian Balai Penelitian Perikanan Perairan Umum. Palembang.

Djohan, T.S. (2008). Ekologi Daerah Aliran Sungai BianKumbe: Perspektif Tata Ruang Kabupaten Merauke (p. 1-10). Makalah Seminar Sehari: Tinjauan Kritis dan Efektif Pemanfaatan Ruang dalam Pendekatan Pola dan Fungsi Ruang di Kabupaten Merauke tanggal 15 November 2008 yang diselenggarakan oleh Forum DAS BIKUMA dan WWF Indonesia berkoordinasi dengan BAPPEDA Kabupaten Merauke.

Effendie, H. (2003). Telaah kualitas air bagi pengelolaan sumberdaya dan lingkungan perairan(p. 257). Kanius: Yogyakarta.

Hubert, N., Kadarusman, Wibowo, A., Busson, F., Caruso, D., Sulandari, S., Nafiqoh, N., Pouyaud, L., Rüber, L., Avarre, J.C., Herder, F., Hanner, R., Keith, P., \& Hadiaty, R. K. (2015).DNA barcoding Indonesian freshwater fishes: challenges and prospects. DNA barcodes(3),144-169.

Husnah \& Wibowo, A. (2012). Karakteristik sumberdaya ikan dan strategi pengelolaan perikanan perairan sungai yang bermuara ke pantai barat Sumatera.Jurnal Kebijakan Perikanan Indonesia. 4(2): 69-78.

JCP. 2012. Water resources management planningand integrated water resources management tools. Document B1.2 PPP Results Einlanden-DigulBikuma basin IWRM case study. Water Mondiaal Partner for water royal Netherlands Embassy in Jakarta.

Kartamihardja, E. S., Purnomo, K., \& Umar, C. (2009).Sumberdaya ikan perairan umum daratan di Indonesia terabaikan.J. Kebijak.Perikan.Ind. 1(1): 115.

Kartamihardja, E. S., N.N. Wiadnyana., S. Koeshendrajana., C. Umar., M.F. Rahardjo., Krismono., \& Fahmi, Z. (2012). Naskah Akademik Penetapan Kawasan Pengelolaan Perikanan di Perairan Umum Daratan Indonesia.(p. 53). Pusat Penelitian Pengelolaan Perikanan dan Konservasi Sumberdaya Ikan. Balitbang KP. 
Kartamihardja, E. S., Purnomo, K., Tjahjo, D. H. W., \& Koeshendrajana, S. (2013). Pendekatan ekosistem untuk pengelolaan sumberdaya ikan arwana irian, scleropages jardinii di Sungai Maro, MeraukePapua.J. Kebijak.Perikan.Ind. 5(2): 87-96.

Keputusan Menteri Negara Lingkungan Hidup No. 115 Tahun (2003) tentang Pedoman Penentuan Status Mutu Air.

Nasution, Z. (2013). Pengembangan kelembagaan nelayan dalam pengelolaan perikanan perairan umum daratan.Orasi pengukuhan profesor riset ( $p$. 75).Bidang sosial ekonomi.Badan Litbang Kelautan dan Perikanan. Jakarta.

Prianto, E., Husnah, Makri, \& Wijaya, D. (2010).Distribusi Longitudinal Ikan Berdasarkan Sumber Polutan di Sungai Musi(pp. 190-240).Prosiding Seminar Nasional Limnologi V Tahun 2010.Cibinong, Puslit Limnologi.

Peraturan Pemerintah Republik Indonesia No. 82 Tahun (2001) tentang Pengelolaan Kualitas Air dan Pengendalian Pencemaran Air.

Peraturan Pemerintah Republik Indonesia No. 26 Tahun (2008) Lampiran VI mengenai Wilayah Sungai.
Rahardjo, M.F., D.S. Sjafei, R. Affandi, Sulistiono \& J. Hutabarat, J.(2011).Iktiology(p. 396). Lubuk Agung, Bandung.

Sentosa, A.A.,\&Satria, H. (2013).Komposisi ikan hasil tangkapan jaring insang di bagian hulu Sungai Kumbe, Kabupaten Merauke, Papua. (p. MD-11: 17). Prosiding Seminar Nasional Tahunan X Hasil Penelitian Perikanan dan Kelautan Tahun 2013 Jilid II: Manajemen Sumberdaya Perikanan. Jurusan Perikanan dan Kelautan Fakultas Pertanian Universitas Gadjah Mada.

Umar, C., Prianto, E., \& Sulaiman, P.S. (2015).Pengelolaan Sumberdaya Perikanan di Sungai Serkap Kabupaten Pelalawan Provinsi Riau.J. Kebijak.Perikan.Ind. 7(2): 71-77.

Utomo, A.D., Adjie, S., Aida, S.N., \& Fatah, K. (2010). Potensi Sumberdaya Ikan di Daerah Aliran Sungai Musi Sumatera Selatan.(pp. 99-206).Monograf Perikanan Perairan Sungai Musi Sumatera Selatan. Balai Riset Perikanan Perairan Umum (BRPPU).

Utomo, A.D. (2016). Strategi Pengelolaan Suaka Perikanan Rawa Banjiran di Sumatera dan Kalimantan.J. Kebijak.Perikan.Ind. $\quad$ 8(1): $14-20$. 